\title{
The War on Terror and the Crisis of Postcoloniality in Africa
}

\section{Kenneth Omeje*}

\begin{abstract}
Back in the early 1990s when a section of the American foreign policy think tank and the intelligentsia were euphorically forecasting scenarios for the consolidation of western victory in the Cold War, James Woolsey, then head of the US Central Intelligence Agency forewarned that the widely celebrated victory and transition to the post-Cold War era was akin to the West, having slain the dragon (of Soviet threat), now living in a jungle full of poisonous snakes (Woolsey 1993). There can hardly be a better metaphoric representation of the post-9/11 projection of American power in the postcolonial world, especially in Africa. This article argues that the US-led war on terror tends to reinforce the crisis of postcoloniality in Africa by deliberately producing metaphors, images, discourses, doctrines and policies aimed at magnifying and mainstreaming terrorism scares on the turbulent politico-economic landscape of Africa, as a means to justify imperial governance and supervision. It is a project that ideologically feeds into influential transhistorical discourses and portrayal of Africa as a timespace of infantilism, requiring endless western propping and chaperoning. Evidently, African political regimes serve as satellite collaborators in the enterprise in a trajectory that the author captures within the discursive framework of postcoloniality.
\end{abstract}

\section{Résumé}

Au début des années 1990, lorsqu'une partie du groupe de réflexion américain en matière de politique étrangère et l'intelligentsia prévoyaient

* Professor of International Relations, United States International University, Nairobi, Kenya.Email: komeje@usiu.ac.ke 
euphoriquement des scénarios pour la consolidation de la victoire de l'Occident dans la guerre froide, James Woolsey, qui était alors le chef de l'Agence centrale de renseignement (CIA) des États-Unis, avait averti que la victoire largement célébrée, ainsi que la transition vers la période d'après-guerre froide, était à l'image de l'Occident, qui, après avoir tué le dragon (la menace soviétique), vit maintenant dans une jungle pleine de serpents venimeux. Il ne peut guère y avoir une meilleure représentation métaphorique de l'image post-11 septembre de la puissance américaine dans le monde postcolonial, en particulier en Afrique. Cet article soutient que la guerre contre la terreur menée par les États-Unis d'Amérique tend à renforcer la crise de la postcolonialité en Afrique en produisant délibérément des métaphores, des images, des discours, des doctrines et des politiques visant à amplifier la peur du terrorisme dans le turbulent paysage politico-économique de l'Afrique. Ceci se trouve être un moyen de justifier la gouvernance et la supervision impériales. Il s'agit d'un projet qui est idéologiquement fondé sur des discours transhistoriques influents et la représentation de l'Afrique comme un espace d'infantilisme, qui nécessite le soutien et le chaperonnage interminables de l'Occident. Evidemment, les régimes politiques africains servent de collaborateurs satellites dans cette entreprise, dans une trajectoire que l'auteur place dans le cadre discursif de la postcolonialité.

\section{Introduction}

Contrary to Crawford Young's (2004) postulate proclaiming the [probable] demise of the postcolonial moment, the postcolonial era has not passed. It has basically been reconfigured and reinvented. Young (2004:23-24) speculates that there has been a demise of the "postcolonial moment' in Africa since about the year 1990. He attributes the historic demise to the convoluted forces of market liberalisation and democratisation in Africa, which have eroded the silent incorporation of many defining characteristics of the colonial state in its post independence successor for the preceding three decades. 1990 is designated as the terminal postcolonial period because this was the year when the unfolding transformations came full cycle with a multitude of new functional and dysfunctional actors (informal traders, smugglers, warlords, arms traffickers, youth militias, local associations, women's organisations, religious groups and refugees) entering the political space and interacting with state agents and international agencies (Young 2004:24-25). In the end, Young details the decay and disintegration of the postcolonial state but fails to tell us what has replaced it and what has become of the sociocultural and sundry concomitants of postcoloniality in Africa. 
I argue in this article that the emerging politics and discourses of imperial chaperoning in Africa and how African political regimes relate to them, midwifing, facilitating and trying to maximise the political and economic opportunities and possibilities attendant to the process attest to the contemporary reinvention of postcoloniality. Incidentally, these processes were already unfolding when Young declared in 2004 that 'the postcolonial moment has passed.' Perhaps, he only needed to have searched a little deeper. Reminiscent of the famous essays of Francis Fukuyama, 'The End of History', and Charles Krauthammer, 'The Unipolar Moment', that both celebrated the end of the Cold War, Young's article presumes that the onset of the crisis of patrimonial decline in the 1980s and the backlash of developmentalism in the 1990s, culminating in the emergency of failed and turbulent states, have conspired to erode the currency and discourse of the postcolonial state, if not the entire project of 'stateness' in Africa (Young 2004:23-49).

The postcolonial state and postcoloniality could not have ended in a sudden 'moment' as the Cold War did when its essential underlying structures (mostly physical) in the communist bloc and the Soviet Union disintegrated. The structures of postcoloniality are both physical and mental/social, such that even if the physical disintegrates, the mental and social component could still sustain and perpetuate the phenomenon for a long time, perhaps for generations. The physical aspect is the political and economic structures inherited from the colonial dispensation, which privilege the metropole (ex-colonial masters and the West) and the local postcolonial political elites. The mental and social aspect, elaborately analysed by Mbembe (2001) and which Young ironically acknowledged, are 'the practices, routines and mentalities' (see Young 2004:23) that reinforce the social relations of postcoloniality. There are two sides to these social relations. The first is the relations between the metropole and postcolonial state, especially the subservient local hegemonic elites. The second is the relations between the postcolonial elites and the subject classes - relations that involve a nexus of coercion, cooptation, manipulation and cooperation, depending on the rhythm of balance of power between the local elite and the disparate subject groups and political constituencies. It is the occasional tendency by many subject communities and groups to cooperate with, and to hero-worship, the hegemonic potentates as 'a fetish to which the subject is bound' that Mbembe (2001:104-1 10) generalised as the 'logic of conviviality' facilitating the smooth running of the potentate's postcolony. 
Suffice it to argue that postcoloniality and the postcolonial state still thrive in both their physical and mental/social forms. The post 9/1 1 discourses, systems and structures of imperial supervision and governance have contributed significantly to a strengthening of the external social relations and structures of postcoloniality. However, the processes tend to weaken the domestic aspect of postcolonial social fabric given the marked resentment and opposition of many African (un)civil societies to the intrigues and role of their political leaders in the anti-terrorism campaign. Put differently, it is apparent that the war on terror is accelerating the breakdown of structures of Mbembe's perceived 'conviviality' between African rulers and sections of their subjects while conversely consolidating the logic of conviviality between the postcolonial political elites in Africa and the metropolitan hegemonies.

\section{Pattern of Underlying Intellectual and Policy Discourses}

Many African states are evidently beleaguered, fractured and straggling. As such, discourses of postcoloniality are awash with concepts, representations and qualifiers that depict most postcolonial and African states as strictly non-state and sub-state human and institutional entities. International Relations (IR) theories, Comparative Political Economy (CPE) and neo-Weberian Historical Sociology (n-WHS) are some of the dominant specialisms that have extensively studied contemporary postcolonial states - their nature, problems and challenges. A dominant feature of many influential studies on the African states within the above specialisms is their western-centric epistemology and its associated tendency to generalise, exaggerate and deride the dysfunctionality of the state in Africa, including their security vulnerabilities and the so-called threats to the outside world. Fragile, malleable, weak, regressive, failed or in the danger of failing - the state in Africa (sometimes categorised without exceptions) is portrayed by mainstream western-centric theorists as posing mortal threats to both its citizens and the 'civilized world'. In the post-9/1 1 world of threat-mongering, there has been a significant and perplexing high level policy buy-in to this philosophy. African security vulnerabilities (real, imagined or exaggerated) are reconstructed into rhetoric of pathological danger. Terror pervades the 'dark continent'. Discourses, doctrines, policies and scenarios of imperial intervention, supervision and governance are developed and unfolded to tame the untamed (i.e. the 'micro-jungle'l and its teeming 'poisonous snakes'). The vulnerable and unruly infant cannot be left unchaperoned. 
Placed in a historical perspective from their establishment under colonial rule to the era of political independence, from decolonisation to the tribulations of state-making, most African and postcolonial states have hardly ceased to fall under direct and indirect western imperial stereotyping, supervision, subjection and governance. Whether in the precolonial (trans-Atlantic slave trade), colonial and postcolonial eras, Africans have been depicted as 'a special human type,' 'a child type' - 'with child psychology and outlook' - 'who can never grow up, a child race' (see Mamdani 1996:4). This vein of ideological construction has provided practical justifications for imperialist interventions in Africa, which have often been couched in such humanitarian discourses and disguises as the necessity to 'civilise', 'reform', 'modernise', 'develop', 'protect', 'liberate', 'emancipate,' and 'strengthen'. In this ideology and discourse of 'help from above' (the West), Africa is portrayed as a timespace of infantilism, requiring endless western propping and chaperoning. The consequence of this is a montage of imperiums that paradoxically 'reform' and 'deform', 'modernise' and 'destabilise', 'develop' and 'underdevelop'. From (pre)colonial mercantilism to the laissez faire imperialism of the Victorian era, from 'post-Second World War liberal internationalism' (Gardner 1990; Mosley 2005) to the post-Cold War unipolar triumphalism (see Krauthammer 2003), African social fabrics are arbitrarily disfigured, unsettled and reconfigured to meet a complexus of 'extraverted interests' (Bayart 2000). African states, peoples and hegemonic elites are consigned to constantly grapple with the changing paradigms of the politics of extraversion, subjection and chaperoning, as well as to compete for the nuanced empowering opportunities and possibilities that unfold.

Until the tragic 9/1 I terrorist incidents, expectations that the end of the Cold War could lead to a 'peace dividend' in the international system remained considerably high, not least among the American public. The successive US administrations, however, did not share this illusion and as such remained committed to what General John M. Shalikashvili (then Chairman of the Joint Chiefs of Staff) in 1996 termed 'full spectrum dominance' (Bacevich 2002:127), marked by a worldwide projection of American military power. Nonetheless, the illusion of the White House and the US foreign policy think-tank that 'the international community is far more likely to enjoy peace under the power projections of a single hegemon' - a phenomenon gratuitously described by Charles 
Krauthammer as 'a uniquely benign imperium' (quoted in Rogers 2002:1 16) - was all shattered by the gruesome events of 9/1 12001 .

In the aftermath of the 9/1 1 incidents, America's post-Cold War unipolar triumphalism and 'full spectrum dominance' have apparently reclined to a systematic militaristic imperium over the vast postcolonial states of Africa and elsewhere in the South. The principal rhetoric of the sprawling imperium is the security of American citizens, American strategic interests and those of its western allies. Within this new configuration of post-9/1 1 imperial governance, African postcolonies, especially the vast Sahalian belt and the interlocking areas of the Arab Maghreb, West Africa, the Horn and Great Lakes regions, with large Islamic populations, are depicted and castigated with a profusion of cognomens and phraseologies aimed to justify US and, to lesser extent, western intrusion, subjection, manipulation and chaperoning and, if necessary, military invasion and occupation. In the foreign policy industries of the US, UK and many EU governments, as well as in mainstream IR, CPE and n-WHS literature, narratives of most African postcolonial states are inundated with despicable images and pathological references such as: 'chaos and barbarism', 'criminal anarchy', 'large uncontrolled and ungoverned territories', 'breeding ground for international terrorists', 'potential havens for terrorist activities', 'hotbeds of instability' 'Tora Bora for talibanisation', 'incorrigibly delinquent countries'(Kaplan 1994; Keenan 2004).

Furthermore, and at a more ideological level, pathological constructions of Africa as a site for terror, insurgency and anarchy have even transcended proposals on the urgency of American imperial governance under the aegis of the war on terror, to some seemingly bizarre discourses on scenarios and possible justifications for 'benign recolonisation.' Robert Jackson, Andrew Linklater, Gerald Helman and Steve Ratner, and other proponents of this view advocate a 'reformation of decolonisation' through 'new instruments of global stewardship' or 'some forms of international government' akin to the mandate system of the defunct League of Nations over 'failed states and failing states and weak states', 'not able to stand on their feet in the international system' (Linklater 1996). Helman and Ratner (1993:12) argue that these forms of 'guardianship and trusteeship' are 'a common response to broken families, serious mental or physical illness or economic destitution' and thus should be invoked on the plight of failed states, preferably by the UN. Benign recolonisation arising from discourses of pathological danger and infan- 
tilism, as in all preceding historical discourses of African vulnerability, is rationalised by a humanitarian rhetoric, notably to bolster state sovereignty and to protect vulnerable populations on the grounds that sovereignty wrongly privileges order over justice (Linklater 1996:108-109; see Morton 2005 for a critique of these views). Proposing a regime of imperial governance to combat terrorism, spread development and salvage failed and failing states, the British ex-Foreign Secretary, Jack Straw, articulates for the West a hypothetical scenario for division of governance responsibilities over 'the new and old Third Worlds.' 'This could mean', argued Straw, 'the EU, NATO or the OSCE (Organisation for Security and Cooperation in Europe) taking the lead in dealing with problems around the margins of Europe; the French or ourselves (perhaps jointly), in parts of Africa and countries like Canada or the US under the OAS (organisation of American States) in the America' (Chandler 2002).

Most discourses and narratives of 'benign recolonisation' (an apparent disguise for imperial diktat) and imperial governance are riddled with superficialities. Pertinent questions such as the underlying socioeconomic circumstances and political specificities of the failed states, as well as the role of disparate conflict stakeholders, including local political elites, regional and external forces are usually glossed over. Instead, state decline, disintegration and breakdown are construed as inexorable congenital and pathological processes. Also, more legitimate possibilities of conflict resolution and state reconstruction such as constructive capacitation and use of regional organisations such as ECOWAS, AU, and SADC are hardly contemplated by these African sympathisers and this is in spite of the recent considerable peacekeeping successes achieved by ECOMOG (the ECOWAS intervention force) in Sierra Leone, Liberia, Guinea Bissau and Cote d'Iviore. ${ }^{3}$ Consequently, a growing number of 'complex political emergencies' (CPEs) in the South (e.g. Cambodia, Somalia, Congo DR, Haiti), including the US preemptive (in reality preventive) wars in Afghanistan and Iraq have shown that it is indeed more difficult to achieve the recomposition and restoration of failed states through a quasi-colonial or neo-imperial extraversion and internationalisation of sovereignty than otherwise. State sovereignty by its very nature - the Westphalia legacy or benchmark - is wary of, and resistant to, internationalisation. The sovereignty of fractured states can be best fixed through proactive processes of 'intra-nationalisation' and regionalisation. Regionalisation of the sovereignty of failed states has 
basically worked in Africa for two apparent reasons. The first is that a large number of civil wars and contemporary CPEs in Africa have profound regional content, a phenomenon associated with the fluidity of peoples among ethnonational groups and communities straddling international borders, the arbitrary nature of most international boundaries and the centrality of lootable natural resources (conflict goods) to African political economies. The second factor is largely sociocultural - the idiom and principles of fraternity, collectivism and synergism, which obligates the African to help extinguish the raging 'fire next door' (Francis 2001:1), thereby 'checkmating' its spread and ruinous effects. This factor is empirically enhanced by the existence of some relatively viable diplomatic and political channels and structures for dispute settlement within African regional organisations, coupled with the use of semi-formal processes of bilateral and multilateral diplomacy.

\section{Rhetoric of Violence, Ingoverned Spaces and Danger}

Extensive consensus exists in the post 9/1 I IR literature that the terrorist events of that fateful day have radically changed how America and Americans perceive the world - that the world is indeed 'a jungle full of poisonous snakes' in which a hegemonic power has never been as despised and vulnerable. It seems to be the case, however, that this dominant discourse is overly generalising. The $9 / 11$ incidents have no doubt affected America's perspectives, perceptions and policies in a radical way but this change is mostly in relation to the Third World, not the world in general. The reason is not far-fetched. The architects of the 9/1 1 attacks were members of an extremist Islamist terrorist group from the Third World - a region that given the extensive asymmetrical power relations between the global North and South should by no rational calculation be able to accomplish a colossal security assault on a world power on its own soil. Hence, despite the obvious political discord between the Bush administration and some of the EU states (notably France and Germany), especially over the Iraq war and the wider contempt of the White House for multilateralism in the name of upholding America's national interests, America's foreign policy and relations with Europe have not changed in any significant manner.

One of the specific consequences of 9/11 for Africa, observes Ali Mazrui (2005:15), is a dawning realisation in the western world that the Muslim presence on the African continent is far more extensive than previously imagined. Nearly the entire Arab Maghreb and Sahel regions, 
a greater part of West Africa and the Horn, as well as significant parts of Central-Eastern and Southern Africa are Muslim populated. Juxtaposed to the pre-9/1 I terrorist bombing of two US embassies in East Africa in August 1998, the prolonged asylum of Osama Bin Laden in Sudan in the mid-1990s where Al Qaeda was believed to have been born, and the perennial Islamist militancy in Algeria, Egypt, Sudan and northern Nigeria, this new knowledge informed a disquieting discourse of 'danger' to the US and its western allies. Paranoia was not far from the scene.

The US invasion of Afghanistan to dislodge the Taliban regime and apprehend $\mathrm{Al}$ Qaeda terrorists and the re-securitisation of the entire Middle East and Pakistan at the onset of the war on terror further meant that Africa must be fully drafted in. Senior officials of US European Command (EUCOM), senior US government officials, CIA counterintelligence reports and western media played a big part in the mainstreaming of Africa using rhetoric and idioms that depicted and blackmailed Africa as 'a potential breeding ground' for Islamist militancy and 'a safe haven for terrorists'. EUCOM has been chiefly instrumental in sensitising the Washington administration to the huge security gaps in Africa, 'emphasizing the vulnerability of US interests to terror, criminality and instability' in the region (CSIS 2005:vii). EUCOM and other protagonists have spoken 'in increasingly exaggerated language of terrorists' 'fleeing the war in Afghanistan' and 'the crackdown in Pakistan' 'swarming across the vast, ungoverned and desolate regions of the Sahara desert - through Chad, Niger, Mali and Mauritania' (Keenan 2004a:477; 2007). Specifically, US European Deputy Commander, Air Force, General Charles Wald reportedly declared:

Although most Americans know very little about the African continent and understand even less about its politics, it is critical that the nation focus on this area now to stem the growth of terrorism. Northern Africa serves as a transit route for terrorists headed to Europe ... East Africa, particularly, has become a hotbed of Al Qaeda elements. Western Africa has witnessed dramatic rises in anti-American and extremist Islamic rhetoric, particularly in northern Nigeria. And in parts of South Africa, we have no clues what is going on ... (Diallo 2005:42).

General James L. Jones, Supreme Allied Commander Europe (SACEUR) and the Commander of EUCOM, pointed this out:

We are seeing evidence that terrorism is moving into Africa, especially the radical, fundamentalist type. The countries on the rim of the 
Mediterranean Sea ... Algeria, Tunisia, Libya and Morocco ....are the most pressing concern for the Command, but failed states further south also pose problems. Terrorists see the continent as a place to hide, a place to train and a place to organize new attacks. While terrorism based in Africa is a long-term threat to the United States, it is a more immediate one to Europe. The Mediterranean that separates Africa from Europe is no longer a physical barrier; it's a pond that people can step over (Noticias. info, September 2004).

Richard Haass (2005), Director of the Policy Planning Staff at the US State Department, added that:

The attacks of September 112001 reminds us that weak states can threaten our security as much as strong ones, by providing breeding grounds for extremism and havens for criminals, drug traffickers and terrorists. Such lawlessness abroad can bring devastation here at home. One of our most pressing tasks is to prevent today's troubled countries from becoming tomorrow's failed states.

Appraising the terrorist threat in Africa in February 2004, General Charles Ford declared that 'the threat is not weakening, it is growing' and 'we can't just sit back and let it grow'(ETaiwannews.com, 2004). With no central government for over 14 years, the failed state of Somalia fell swiftly into the bad faith of protagonists. Somalia has been hyped as a safe haven for terrorists uprooted from the Middle East and the various warlords and militia groups in the country are said to be funded by Middle Eastern terrorist mafia. Nearly all Islamist fundamentalist groups in North Africa and the Sahel, including those waging political struggles prior to 9/1 I have been branded 'Al Qaeda subsidiaries', 'surrogates', 'sympathisers,' 'subcontractors' and 'beneficiaries of international Jihadist funding.' The proximity of North Africa to Europe and the Middle East has also been exaggerated to allege that terrorist organisations and $\mathrm{Al}$ Qaeda cells from the Sahara are infiltrating Europe through the backdoor (Diallo 2005:25-30). Subsequent incidents of terrorist bombings in Djerba-Tunisia (April 2002), Mombassa-Kenya (November 2002), Casablanca-Morocco (May 2003), the repeated terrorist attacks on western tourists in Egypt before and after 9/11, and the kidnapping of 32 western tourists (mostly Germans and Austrians) in the Algerian desert (April 2003) have been high-profiled by the US and its allies to declare Africa north of the equator a zone of terror. A large part of the redefined 'zone of terror', especially the Sahel-Central Africa-Great Lakes axis, is evidently blighted by a convolution of HIV/AIDS pandemic, food defi- 
cits, and paramilitary insurgencies. These trends not only support an apparent theory that many are vulnerable to recruitment into terrorist violence in Africa, but also add pathologies of 'disease,' 'peonage', and 'disorder' to the rhetoric of 'danger,' ipso facto fulfilling the ideological conditions for a systematic military securitisation.

\section{Politics of Hegemony and Subjection}

US hegemony in the international system and the subjugation and chaperoning of Africa and the Third World is clearly an old game that preceded 9/1 I and even the demise of the Cold War. The imposition of neo-liberal economic reform and structural adjustment programmes (with all their devastating conditionalities) on many developing countries using the World Bank and International Monetary Fund (IMF) is a familiar discourse in 'international political economy' (IPE) literature (Hoogvelt 1997; Abrahamson 2000). The 'invisible hand' of the US administration in the prescription and implementation of the IMF/World Bank neo-liberal therapies in the South from the early 1980s onwards is best captured by what is known in IPE as 'the Washington Consensus' referring to the alliance of the two Bretton Woods institutions and the White House in the programmed manipulation, control and exploitation of the economies of Third World-policy beneficiaries, using such neo-liberal measures as privatisation of state enterprises, currency devaluation, cuts in social spending, crippling credit facilities, debt-equity swap, and sundry patterns of deregulations. There is an avalanche of well-grounded empirical studies in both CPE and IPE linking a great deal of the contemporary economic hardship, state failure, insurgencies, breakdown in state governing institutions and civil wars in Africa and elsewhere in the South to the devastating effects of the World Bank/ IMF neo-liberal economic policies.

The Bush administration came to power with a clear agenda of how to spread, entrench and consolidate American hegemony - a discourse eloquently articulated in its September 2002 National Security Strategy (NSS), promulgated one year after $9 / 11$. It suffices to underscore that the NSS was largely a synthesis of preceding neo-conservative manifestos on the projection of American global hegemony, notably the 1992 Defence Policy Guidance of the older Bush Administration and the 2000 report of the Project for the American Century. Influential drivers of these preceding manifestos included ex-Deputy Defence Secretary and until recently World Bank President, Paul Wolfowitz, ex-Defence Sec- 
retary Donald Rumsfeld and Vice President Dick Cheney. Among the major policy discourses of the NSS are to:

- Maintain America's unparalleled military strength and dominance;

- Combat global terror, if necessary, by pre-emptive action;

- Enhance American energy security by expanding sources and types of global energy supplied, especially from the Western hemisphere, Africa, Central Asia and the Caspian region;

- Deter threats against US interests, allies and friends (US State Department 2002).

Whilst these discourses and guidelines could theoretically be well-meaning and constructive, it is, however, evident from unfolding realities that they represent the hegemonic ideology and imperial project of post 9/1 I neo-conservative America. How do the NSS policy discourses interlink the rhetoric of danger and the imperatives of hegemonic domination and chaperoning of Africa?

Having mapped out Africa north of the equator as a zone of terror, the US administration has promulgated a range of counter-terrorism doctrines, policies and strategies. The central aim of the new US initiative or at least the official rhetoric behind it is to develop the counterterrorism capacity of African states, enhance state capacities to secure their borders, and to generally 'help Africans to help themselves' (Noticias. info). But beyond the smokescreen and rhetoric of 'helping Africans to help themselves' lies America's strategic design to project its national power and ensure the domination, chaperoning, supervision and conformity of Africa to the goal and imperatives of US imperial governance. African governments and regional organisations have all been mobilised in pursuit of the American post 9/1 l imperial vision and are now being constantly pressured, blackmailed and monitored to stay on track. At the behest of the US administration, the AU has established in Algiers an African Centre for the Study and Research on Terrorism (ACSRT) to bolster the capacity of the Union in the prevention and combating of terrorism in Africa through research, documentation, information dissemination, training, and seminars. The ACSRT is largely funded by the US and other western partners. The choice of Algiers as location for the ACSRT is strategic. The main reason for the choice is that the Algerian government is one of the staunchest allies of the Bush 
administration in the war on terror in Africa and there is a logic of vital mutual interests at play in the bilateral engagement. For its part, the US is interested in securing Algerian oil and gas resources for both itself and major European allies. Consequently, Washington is interested in keeping the Islamists in Algeria and North Africa at bay to ensure that they do not pose any serious threats to US and western energy security interests as they have done in the Persian Gulf. President Abdelaziz Bouteflika's government in Algeria, on the other hand, is desperate to acquire modern American military weapons to strengthen its underequipped army embroiled in a long-drawn-out battle with various local Islamist groups since 1992. The armed struggle arose in the aftermath of the government's annulment of the January 1992 Algerian parliamentary elections in a bid to prevent the radical Islamic Salvation Front (known by its French acronym, FIS) from ascending to power and possibly imposing an Iranian Islamic republic model. France (Algeria's former colonial power) and the US have backed the Algerian government in the ensuing disruptive insurgency, which have claimed more than 100,000 lives and many analysts have also implied a Washington-Paris complicity in the 1992 election annulment. The pro-establishment position of France and US in the conflict has been used by insurgents as an excuse to specifically target and attack western nationals and tourists in Algeria. Boutefilka and senior Algerian government officials have paid repeated visits to Washington since $9 / 11$ to register support for the war on terror and negotiate military assistance while senior US government officials have also paid reciprocal visits to Algiers. Under the influence of the American government and in a bid to attract expanded military assistance (from the Algerian government's perspective, US military and financial assistance is still considered inadequate) the Bouteflika government has intensified its crackdown on local opposition and Islamist groups who are all labelled Al Qaeda affiliates (CFR 2004). Despite the deplorable human rights conditions, the Algerian government's massive crackdown (killing, torture, incarceration) has considerably mitigated local insurgency and the activities of radical Islamic groups, notably the Armed Islamic Group (GIA - the paramilitary wing of FIS) and its splinter group, the Salafist Group for Preaching and Combat (GSPC), that both seek to overthrow the regime in Algiers.

Whereas Algiers is America's outpost for 'imperial policing' of the Arab Maghreb, Bamako-Mali (where the US has an airbase) occupies a similar position in the Sahel as headquarters for the US Pan-Sahel Ini- 
tiative (PSI) established in November 2002 by the State Department. Another US 'policing' initiative, the East African Counter-Terrorism Initiative (EACTI), has its operational base in Djibouti. EACTI comes under the US Joint Task Force for the Horn of Africa created in 2002 and comprises Djibouti, Uganda, Tanzania, Eritrea, Sudan, Ethiopia, and Kenya. EACTI is coordinated by some 1,800 US troops from their Camp Lemonier base in Djibouti and the strategic importance of the base lies in its proximity to the Arab Peninsula, especially Saudi Arabia and Yemen - two countries perceived by the US as breeding grounds for international terrorism (Diallo 2005). In June 2003, President Bush announced a $\$ 100$ million financial provision for the EACTI. Since June 2005, The Algerian project and PSI have been loosely coalesced to form the TransSahara Counter-Terrorism Initiative with the aim of fostering co-operation between the various states of the two regions classified as 'terrorist hotbeds and safe havens' - Algeria, Chad, Egypt, Mali, Mauritania, Morocco, Niger, Senegal, Nigeria and Tunisia, with possibilities of Libya coming on board as Washington-Tripoli relations improve (Global Security 2005). Top military officers of most of the above countries have taken part in strategic meetings and training programmes at the EUCOM headquarters in Stuttgart (March 2004) and elsewhere in the west on the war on terror. EUCOM in partnership with Pentagon and the State Department Office of the Coordinator for Counterterrorism is the central coordinating agency and clearing-house for all the counter-terrorism projects in Africa. Through these projects, the US provides military training and equipment (night vision devices and surveillances systems, assorted conventional weapons, tactical communication gadgets, patrol jeeps, etc.) to enhance the states' capacity for rapid response, border patrol, intelligence monitoring and security cooperation among states. Thousands of Special US forces, marines and security contractors have been despatched into various countries to help strengthen the capacity of local security forces in counter-terrorism. All participating member states have been compelled to establish counter-terrorism security structures, mostly involving special departments, field outposts, task forces and combat squads.

More recently in July 2007, President Bush announced the establishment, with effect from 30 September 2007, of a separate unified combatant Command - the United States' African Command (AFRICOM), naming distinguished Army General William E. Ward as its first Commander. The Command, which is said to have a trans-military mandate 
(i.e. health, humanitarian aid, diplomacy, and most importantly, military) will temporarily operate from the EUCOM facilities in Stuttgart, Germany until sometime in 2008 when it will eventually be headquartered in Africa. The Liberian government has already offered to host AFRICOM amidst pockets of apprehension and opposition from a number of African states (notably Nigeria) concerning the implications that the stationing of American forces in the Gulf of Guinea under any guise would have for state sovereignty and security of the region (This Day 14.09.07).

In a broad sense, funding of the US counter-terrorism projects in Africa is interfaced with the US and EU general funding for security sector reforms (SSR) and support for the development of peacekeeping capacities of states and regional organisations, and in terms of concrete dividends, only a few countries have derived significant support (Washinton Post 2004). As part of the initiatives to support the African Union peacekeeping operations, especially in Darfur, the US government pledged $\$ 660$ million aid to Africa over a five-year period, out of which approximately $\$ 480$ million is targeted for the military sector, including expanding capacities for counter-terrorism and peacekeeping (Martin 2004:588; Kitissou 2005:22). A variety of other US tokenistic aid benefits (mostly bilateral) have followed since then. No doubt, the enthusiasm (including manifest rhetorical and ideological support) of participating African governments in the anti-terror campaign remains substantially high and most regimes are hopeful that the exercise has prospects of yielding more concrete benefits in due course. As part of the growing war on terror, President Bush has moved farther and faster than any recent US administration in constructing a network of military and political alliance, with military-to-military linkages being expanded all across the continent (Martin 2004:587).

Another dimension of the post-9/1 I stretching of the anti-terrorist dragnet is that sections of American intelligentsia (and the rest of the West, to a lesser extent) have increasingly tried to draw a connection between the African diaspora populations and allegations/potential of both terrorism and political insurgency in their home countries on the African continent. The intellectual precursor of this 'wild chase' goes back to the various works of the World Bank Development Research Group in the 1990s to early 2000s suggesting that through their financial remittances to their families, relatives and so forth, the African diaspora plays a prominent role in promoting domestic insurgencies and armed conflicts in their home countries (cf. Collier \& Hoefller 2000; 
Collier 2000a; Collier 2000b). Expounding the viewpoint that the African diaspora provide 'financial safe havens' conducive to terrorist activities, Andre Le Sage (2007:9-10) of the US National Defence University - an ideological think-tank of the Pentagon - argues that:

African countries are [also] vulnerable to terrorist efforts to mobilize and transfer funds for their operational purposes. An estimated \$125 billion moves through the remittance, or hawala, economy each year, and many countries are highly dependent on remittances for their financial well-being. Remittance systems are largely unregulated arrangements for money transfers based on trust. They are particularly popular among diaspora communities to send relatively small amounts of money to family abroad in a way that helps avoid taxes and fees and reaches locations where traditional banks are not present. International pressure has induced larger remittance companies to adopt some minimum standards of information collection regarding customers. However, efforts that over-regulate or close remittance companies do not stop the practice of hawala, but rather they push it further underground and out of sight. There is also the special case of South Africa ..., which has sophisticated financial systems that are not yet adequately monitored or regulated and may be subject to abuse.

It is a priori connections and exaggerations such as the above that account for the growing tendency of undue suspicion, profiling, surveillance, monitoring and persecution of many Africans by the state security apparatuses in the US and a number of other western countries in the aftermath of the events of 9/1 12001.

It is significant that while the US administration largely (but not exclusively) securitises the military aspects of the war on terror in Africa, its closest western ally, the UK government mainly securitises the developmental aspect - problems of economic decline and poverty believed to catalyse Africans' vulnerability to recruitment into international terrorism. Ex-Prime Minister Tony Blair's Commission for Africa and his G8 diplomacy have solidly articulated the rhetoric of 'war against poverty' in Africa, and these initiatives are not without some positive impact or prospect. "For the British government, the "war on terrorism" and the "war on poverty" are two sides of the same coin' (Abrahamson 2004:681). Both allies also operate a bit of each other's specialism in the anti-terrorism campaign. The Bush administration has considerably increased its development budget for Africa while the Blair government launched a mainstream counter-terrorism programme for Africa, Asia and the Middle East in May 2003. 


\section{Exaggeration, Deception, Manipulation and Counter-hegemony}

Clearly, one is not saying that there are no terrorists in Africa. To make any such claim or denial would be as ridiculous as asserting that there are no terrorists in the Middle East or Europe for that matter. At the same time, there are gradations of conflict-prone, war-torn and dysfunctional states in Africa. Indisputably, many African states lack the capacity and resources to extend state governance institutions and de facto political power to the entire geodemographic space that falls under the juridical sovereignty of the state. Also, the porosity of African states' national borders is a well-known fact. In effect, the case built up to securitise and mainstream Africa into the war on terror has considerable elements of truth. But one must hasten to add that these are half-truths. The narratives of protagonists of post-9/1 1 imperial governance and antiterrorism campaign in Africa are founded on the age-old axiom that 'it is easier to twist a half-truth than to tell an outright lie'. Given Africa's position of weakness (in political, economic and discursive terms) one would almost certainly get away with a twisted allegation that terrorists are roaming the vast open Sahara as opposed, for instance, to a similar allegation that terrorists are marauding the vast open Australian desert. Whereas the Australian government could easily navigate and investigate its desert to ascertain the veracity of the report, most states in the Sahara may not bother to verify the news in the first place, not only because they may not have the resources to do so, but also because the Sahara is a shared open desert with more than nine state stakeholders. Shared deserts are by nature difficult to police, not least by poor and beleaguered states. It is such natural and structural disadvantages that protagonists of the war on terror exploit to twist and exaggerate charges of terrorism in Africa.

A related point is that allegations of terrorism and the campaign to combat it serve the dual interests of the neopatrimonial elites and governments of most countries in the terror zone who are also loyal allies in the war on terror. Firstly and on the external front, the phenomena help the African political regimes to hobnob and romance with the US and its western allies with the aim of securing financial and military aid, as well as debt forgiveness and general support for development programmes. From the perspective of the African governments, supporting the USled anti-terrorism campaign is a much preferred conditionality for external aid than the World Bank/IMF stricture - a more rigorous and crip- 
pling package that the anti-terror alliance has shown prospects of abating. In his review of how the US Africa policy has changed post 9/1 I, William Martin pointed out that in the starker post 9/1 1 era, the language of imposing neo-liberal development and democratisation has been replaced by the language of demand for support for the war on terror (Martin 2004:586).

On the domestic front, the anti-terror campaign provides Africa's political regimes with a great opportunity to, with the blessings of the west, persecute and liquidate political opposition, including rival ethnonational groups and communities, under trumped-up terrorism charges. Under the disguise of fighting terrorism, old political scores are unravelled and news frontiers of opposition are imagined and confronted with brutality by regimes already profoundly threatened by a nemesis of chronic corruption and misrule. The governments of Mali and Niger have increasingly incriminated their disgruntled Tuareg minorities and other excluded nomadic desert tribes in the war on terror - potentially restive groups that have protested their exclusion with mass rebellions in the 1990s - and have on that premise carried out a systematic persecution of these groups (Keenan 2004b:693; 2006). Occasional incidents of ordinary highway and desert robbery in these minority regions have been blown-up and attributed to 'local terrorists'. The embattled governments of Mauritania and Chad have linked recent incidents of attempted military coups in their countries to dissidents of local and external Islamist elements opposed to their pro-western stance on the war on terror. These fictitious explanations that say nothing about the crony capitalism, tribal prebendalism and unpopular foreign policies of these regimes - palpable symptoms of misgovernance that have fuelled local discontent and rebellion - have been used as an excuse to crackdown on disgruntled desert nomads, as well as to blackmail unfriendly neighbouring governments alleged to have sponsored the terrorism-related abortive coups. The desperate initiatives of some local African governments overwhelmed by the challenges of regime survival in orchestrating and twisting allegations of terrorism is always a welcome news for western governments and media because they reinforce the discourse of 'danger in the jungle' and the need for anti-terror militarisation. In a similar vein, Jeremy Keenan and other recent researchers have uncovered an increasing amount of evidence to suggest that the high-profiled Algerian hostage-taking incident of April 2003 variously attributed to Mokhtar ben Mokhtar (a local Islamist warlord) and famous GSPC leaders like Hassan Hattab 
and Abderrezak Lamari, was initiated and orchestrated by elements within the Algerian military establishment, with a possible US complicity, to hype the vulnerability of the Sahara to terrorism (Keenan 2004a:482485). This sort of conspiracy is not far-fetched because deception, exaggeration and alarmism are all a well acknowledged part of the stylistics of the anti-terror crusade.

From Nouakchott to Djibouti, from Abuja to Cairo, African governments are chaperoned to prove what Mazrui (2005:15) calls 'their antiterrorist credentials to the United States' and this pressure drives many regimes to step up repression of sections of the local Muslim populations. State-society relations become more fractured and fragmented. Intense pressure has also been brought on many African states to adopt and implement anti-terrorism legislation, a process that the State Department supervises through the various counter-terrorism initiatives. The US is expanding the number of its air bases and landing rights in Africa and elsewhere in the global South.

A major fallout of the anti-terrorist campaign in Africa is its inflammation of Islamist fundamentalism and anti-Americanism. In other words, the campaign activates and inflames discourses and activisms of counter-hegemony. The civil and uncivil societies in Africa are increasingly incensed by America's invasion and arrogant display of power, and this has led to protests against satellite regimes entangled in the imperial agenda. Consequently, anti-American and, to a lesser extent, anti-western sentiments have fed into and aggravated Christian-Muslim relations because of the evident import of 'civilisational warfare' that derives from the campaign. It also pitches radical Islam against the moderate wing, further proliferating the frontiers of violent and structural sectarian conflicts. The structures of these religious conflicts often intersect with other structures of identity and fragmentation in both the state and society (notably race and ethnicity), which potentially make them more deadly and devastating. The impact of these devastating conflicts could be seen in Sudan, Guinea, northern Nigeria, Algeria, Mauritania, Chad, and Mali.

At another level, the repeated rhetoric of 'danger in the jungle' yammered by international media and various western governments in their travel advice to their nationals has extensively damaged the desert, beach and safari economies of the Maghreb, Horn and Great Lakes regions that are largely dependent on international tourism. This phenomenon has thrown many locals out of jobs and reduced the fortune of the local tourist economies. People are naturally exasperated. Discourses and effu- 
sion of counter-hegemony sentiments and anti-Americanism are inevitable in the circumstance. Vulnerability to terrorist recruitment - the very thing dreaded by the West - becomes more likely.

The strong connection between the war on terror and the US energy security, especially the need to secure expanded and uninterrupted oil supplies from the Gulf of Guinea and elsewhere in Africa to compensate for the intermittent shortfalls from the highly volatile Persian Gulf is well documented in IPE literature and cannot be revisited here for lack of space. Suffice it to highlight that America is currently energising the Gulf of Guinea Commission, a regional security organisation proposed by ex-President Obasanjo of Nigeria for the key oil-producing states of Angola, Cameroun, Gabon, Equatorial Guinea, Congo-Brazzaville and Nigeria to help co-ordinate peace and security programme within the region. In 2004, EUCOM commenced the development of a coastal security programme in the region known as the Gulf of Guinea Guard on account of its estimation of vulnerability and threats to the US extensive oil investments in the region (CSIS 2005: 14). The ultimate plan of EUCOM is to integrate the Gulf of Guinea security agenda into the Trans-Sahara Counter-Terrorism Initiative. 'According to the US National Intelligence Council, the United States, in diversifying its sources of oil, can be expected to increase its reliance on the Gulf of Guinea from the current level of 15 per cent to 25 per cent of US oil imports by 2015' (CSIS 2005:13). US strategic energy sources estimate that the Gulf of Guinea will enjoy over $\$ 33$ billion in onshore and offshore oil investments from 2005-2015, more than 40 per cent of which must come from American companies (CSIS 2005:24). The US partly wants to use its vast military and political influence over the Gulf of Guinean states to keep the Chinese at bay against the backdrop of the dramatic increase in Chinese competition and the share of African oil investments and supplies in recent years.

\section{Conclusion}

The US-led war on terror marks the apogee of American imperial governance, global domination and politics of chaperoning the relatively weak African states - processes that tend to aggravate the crisis of postcoloniality on the continent. Antecedents of this phenomenon abound in the past and contemporary projects of western imperial stereotyping, subjection, supervision and governance of Africa and the Third World. The war on terror converges and expresses the various strands of this 
hegemonic politics - international militarism, preemptive warfare, unilaterialism, expanded control over external oil resources, and 'embellished' developmentalism. To deliver this imperial project in Africa, transhistorical discourses and metaphors that portray the continent as a timespace of unmitigated danger and infantilism are reinvented to win support and justification for the project. Like in preceding phases and dispensations of extraversion, most African post-colonial governments have cashed in on the opportunities and possibilities intrinsic to the anti-terror campaign (albeit, not without considerable pressure from the western protagonists) to shore up their highly beleaguered regimes and re-assert their hegemonies.

The current wave of Islamist terrorism with its proclivity to suicide bombing clearly horrifies and puzzles modern western sensibilities. From the perspective of right wing conservative America and the west, it is only the modernity-resistant bad Muslims of African and Middle Eastern origin that are capable of such savagery (see Mamdani 2004:19). Without delving into the historical antecedents and motivations of Islamist terrorism, it suffices to say that Islamist terrorism and terrorist attacks of all kinds are bad for the west, bad for Africa and the Middle East and bad for humanity. As Boroumand and Boroumand (2002:6) have argued, contemporary forms of Islamist terrorism are an ideological and moral challenge to both traditional Islam and liberal democracy woven from appeals to tradition, ethnicity and historical grievances both old and new, along with a powerful set of religious sounding references to 'infidels', 'idolaters', 'crusaders', 'martyrs', 'holy wars', 'sacred soil', 'enemies of Islam', 'the party of God', and the 'great Satan'. These discourses, rhetoric and metaphors are as unsavoury as some of the transhistorical discourses and stereotypes on Africa highlighted in the forgoing analysis. Such constructs and discourses would always lead to hate and contempt, domination and resistance, violence and war. What we see in the war on terror is a 'hysterical overreaction' (Mueller 2005:229) to an exaggerated security threat. John Mueller (2005:208) has demonstrated in a recent empirical study that exaggeration of foreign threats and overreaction to them, as exemplified by the current concerns over international terrorism, have remained a common feature of the US foreign policy, at least since 1945. As the consequences have shown, the present war on terror is apparently a bad response to a bad phenomenon, hence the seemingly bad outcome. 
In the final analysis, the war on terror is its own nemesis. The campaign is conducted and conveyed in a manner and style that seems calculated to humiliate, subjugate and infuriate the Third World. The German news magazine Der Spiegel pre-9/1 I criticism that by its military unilateralism the US was conducting itself 'as the Schwarzenegger of international politics: showing off muscle, obtrusive, intimidating' (quoted in Rapkin, 2005:396) cannot be more appropriate. Unlike previous conventional wars and the Cold War prosecuted by the US that had clearly identifiable adversaries, America has today stretched itself too thinly in a costly and seemingly endless war against more or less globalised invisible adversaries. If the war drags on, one cannot rule out the tendency that many children yet unborn in parts of the global South could grow up, become radicalised and opt to continue the guerrilla fight because of its intrinsic Armageddonic discourse. Given that this is a war unlikely to ever produce a decisive winner in both the short and long run, it is almost inevitable that the US government would at some point rethink its present bellicose foreign policy. With more than 3,800 American soldiers killed and over 8,000 wounded in the Iraq war (figures as at September 2007), the Bush administration has come under increasing domestic pressure from sections of the American public and Congress to withdraw American troops from the war-torn Gulf state. But markedly concerned with face-saving, it is unlikely that the present tough-talking, neo-conservative regime in Washington would easily yield to domestic pressure and pull out American forces from Iraq. Unless the insurgents in Iraq are able to gain and maintain a devastating combat advantage over the US-led coalition forces - a scenario that is most unlikely domestic political pressure in the US may not succeed in compelling the Bush administration to withdraw American forces. A post-Bush White House is therefore more likely to rethink, reinvent and mellow America's imperial governance project, and possibly bring the Iraq war to an end - most likely, without a decisive winner. But whether that is likely to fundamentally affect the way Africa is perceived, constructed, portrayed and chaperoned is a completely different ball game. The politics and methods of imperial supervision could change, but one cannot be so certain about the underlying philosophy, ideology and stereotypes. 


\section{Acknowledgement}

I gratefully acknowledge the Allan \& Nesta Ferguson Trust for funding my 2-year research fellowship in the Africa Centre, University of Bradford during which this study was carried out.

\section{Notes}

1 The international system is the metaphoric 'macro-jungle'.

2. Mohammed Ayoob has reclassified the Third World into two. The new Third World refers to states in Central Asia, Caucasus and the Balkans that have emerged out of the disintegration of the Soviet Union and the dismemberment of Yugoslavia. The post-colonial states of Africa, Asia and Latin America traditionally considered as the Third World are re-defined as the old Third World. The two Third Worlds are described as broadly sharing similar characteristics. See, M. Ayoob, 2001, 'State Making, State Breaking and State Failure' in Chester A. Crocker et al, eds., Turbulent Peace: The Challenges of Managing International Conflict. Washington, USIP Press, pp. 127-128.

3 ECOWAS stands for Economic Community of West African States, AU is the African Union and SADC is the Southern African Development Community.

\section{Reierences}

Abrahamson, R., 2000, Disciplining Capitalism: Development Discourse and Good Governance in Africa, London: Zed Books.

Abrahamson, R., 2004, 'A Breeding Ground for Terrorists? Africa and Britain's War on Terrorism', Review of Africa's Political Economy, 31/102, pp. 677-684.

Ayoob, M., 2001, 'State Making, State Breaking and State Failure' in Chester A. Crocker et al eds., Turbulent Peace: The Challenges of Managing International Conflict. Washington, USIP Press, pp. 127-128.

Bacevich, A. C., 2002, American Empire: The Realities and Consequences of US Diplomacy, Cambridge-Massachusetts, Harvard University Press.

Boroumand L. \& Boroumand R., 2002, 'Terror, Islam and Democracy', Journal of Democracy, 13/2, pp. 5-20.

CFR, 2004, 'Armed Islamic Group and Algerian Islamists,' Council on Foreign Relations, http://cfrterrorism.org/groups/gia2.html\#Q13, Website accessed in August 2005. BBC, 2004, 'Algeria Gives US Terror List', BBC, 'Algeria Winning from the War on Terror', BBC News, 26 April, http://news.bbc.co.uk/1/ hi/world/africa/3659555.stm, Website accessed in August 2005. 
Chandler, D., 2002, 'Jack Staw's Colonial Discourse', Spiked Politics, 10 September, http://www.spiked-online.com/Articles/00000006DA2A.htm, Website accessed on 11 September 2005.

Collier, P. and A. Hoefller, 2000, Greed and Grievance in Civil War. World Bank, http://www.worldbank.org/research/conflict/papers/greedgrievance_23oct.pdf, Website accessed on 28 April 2006.

Collier, P., 2000a, 'Doing Well Out of War: An Economic Perspective', in M. Berdal and D. Malone eds. Greed and Grievance: Economic Agendas in Civil Wars, Boulder, CO: Lynne Rienner, pp. 91-111.

Collier, P., 2000b, 'Economic Causes of Civil Conflicts and their Implications for Policy.' World Bank Development Research Group. http://www.worldbank.org/ research/conflict/papers/civilconflict.pdf, website accessed on 19 September 2007.

CSIS, 2005, A Strategic US Approach to Governance and Security in the Gulf of Guinea, A report of the Centre for Strategic and International Studies (CSIS), Washington DC, Task Force on the Gulf of Guinea Security, July.

David Chandler, 2002, 'Jack Staw's Colonial Discourse', Spiked Politics, 10 September, http://www.spiked-online.com/Articles/00000006DA2A.htm, Website accessed on 11 September 2005.

Diallo, G., 2005, 'Terrorism in Africa is the New Name of the Game', Africa Renaissance', 2/1, January/February, pp. 38-49.

ETaiwannews.com, 2004, 'United States Increases its Military Clout across Africa', 29 February, http://www.etaiwannews.com/World/2004/02/29/ 1078026919.htm, Website accessed on 1 September 2005.

Francis, D. J., 2001, 'The Fire Next Door: Regional Diplomacy and Conflict Resolution in West Africa,' African Review of Foreign Policy, 2/2, January, pp. 1-28.

Gardner, R. N., 1990, 'The Comeback of Liberal Internationalism', The Washington Quarterly, 13/3, September, pp. 23-39.

Global Security, 2005, 'Trans-Sahara counter-Terrorism Initiative (TSCTI)', June, http://www.globalsecurity.org/military/ops/tscti.htm, Website assessed in September 2005.

Haass, R. N., 2003, 'Planning Policy in Today's World', 22 May. http://www. State.gov/s/p/rem/2003/20910.htm, Website accessed on 5 September 2005.

Helman G. B. \& Ratner, S. R., 1992-93, 'Saving Failed States', Foreign Policy, 89, Winter, pp. 3-20.

Hoogvelt, A., 1997, Globalisation and the Post-colonial World, London: Macmillan.

Jackson, H. R., 2000, The Global Covenant: Human Conduct in a World of States. London: Oxford University Press.

Jean-Francois, B., 2000, 'Africa in the World: A History of Extraversion', African Affairs, 99/395, pp. 217-267. 
Kaplan, R. D., 1994, 'The Coming Anarchy', The Atlantic Monthly, 273/2, pp. 44-76.

Keenan, J., 2004a, 'Terror in the Sahara: the Implications of US Imperialism for North \& West Africa', Review of African Political Economy, 101/31, pp. 497-511.

Keenan, J., 2004b, 'Political Destabilisation and Blowback in the Sahel', Review of African Political Economy, 31/102, December, pp. 691-698.

Keenan, J., 2006, 'Security and Insecurity in North Africa.' Review of African Political Economy, 33/108, pp. 269 -296.

Keenan, J., 2007, 'The Banana Theory of Terrorism: Alternative Truths and the Collapse of the 'Second' (Saharan) Front in the War on Terror', Journal of Contemporary Africa Studies, 25/1, pp. 31-58.

Kitissou, M., 2005, 'Political Violence, Terrorism and Counter-terrorism in Africa in the Global Context', African Renaissance, 2/1, pp. 19-24.

Krauthammer, C., 2002/2003, 'The Unipolar Moment Revisited', The National Interest, Winter, pp. 5-17.

Linklater, A., 1996, 'Rationalism', in Scott Burchill et al eds., Theories of International Relations, London: Macmillan, pp. 93-1 18.

Mamdani, M., 1996, Citizen and Subject: Contemporary Africa and the Legacy of Late Colonialism, Princeton: Princeton University Press.

Mamdani, M., 2004, Good Muslim, Bad Muslim: America, the Cold War, and the Roots of Terror, New York: Pantheon Books.

Martin, W., 2004, 'Beyond Bush: The Future of Popular Movements \& US Africa Policy', Review of African Political Economy, 31/102, pp. 585-597.

Mazrui, A., 2005, 'Between Global Governance and Global War: Africa Before and After September 1 1', African Renaissance, 2/1, January/February, pp. 9-18.

Mbembe, A., 2001, On the Postcolony, California: University of California Press.

Morton, A. D., 2005, 'The Failed State of International Relations', New Political Economy, 10/3, September, pp. 371-380.

Mosley, L., 2005, 'Globalisation and the State: Still Room to Move?', New Political Economy, 10/3, pp. 355-362.

Mueller, L., 2005, 'Simplicity and Spook: Terrorism and the Dynamics of Threat Exaggeration', International Studies Perspectives, 6, pp. 208-234.

Omeje, K., 2005, 'Terrorism in Africa Post 9/1 1: Beyond the Emerging Western Consensus', Africa Renaissance', 2/1, pp. 25-30.

Noticias.info, 2004, 'European Command Combating Terror Threats in Africa', 8 October. http://www.noticias.info/Archivo/2004/200410/20041009/ 20041009_35557.shtm, Website accessed on 1 September 2005.

Rapkin, D. P., 2005, 'Empire and its Discontents', New Political Economy, 10/3, September, pp. 389-412.

Rogers, P., 2002, 'The United Nations and the Promotion of Peace', Medicine, Conflict and Survival, 18, pp. $110-119$. 
Sage, A. L., 2007, 'Terrorism Threats and Vulnerabilities in Africa' in Andre Le Sage (ed.) African Counterterrorism Cooperation: Assessing Regional and Subregional Initiatives. Washington: African Centre for Strategic Studies (ACSS), National Defence University \& Potomac Books Inc., pp. 1-38.

This Day, 2007, 'Nigeria Moves to Halt US Military' This Day 14.09.07. http:// allafrica.com/stories/200709140010.html, Website accessed on 15.09.07.

US State Department, 2002, The National Security Strategy of the United States of America, September, http://www.whitehouse.gov/nsc/nss.pdf, Website accessed on 2 September 2005.

Washington Post, 2004, 19 April. See also, Kitissou, K., 2005, 'Political Violence, Terrorism and Counter-terrorism in Africa in the Global Context', African Renaissance, 2/1, pp. 19-24.

Woolsey, J., 1993. 'Testimony to Senate Hearing', Washington DC, February. Quoted in Rogers, P., 2002, 'The United Nations and the Promotion of Peace', Medicine, Conflict and Survival, 18, p. 116.

Young, Y., 2004, 'The End of the Postcolonial State in Africa? Reflections on Changing African Political Dynamics,' African Affairs 103, pp. 23-49. 